J. Dairy Sci. 92:1827-1827

doi:10.3168/jds.2009-92-4-1827

(c) American Dairy Science Association, 2009.

\title{
Erratum to "Effect of dietary protein content on animal production and blood metabolites of dairy cows during lactation" (J. Dairy Sci. 92:1001-1012)
}

\author{
R. A. Law, F. J. Young, D. C. Patterson, D. J. Kilpatrick, A. R. G. Wylie, and C. S. Mayne
}

In Table 2 (page 1004), the DM contents of grass and maize silage are incorrect for the 3 diets. The DM content of grass silage should be $266 \mathrm{~g} / \mathrm{kg}$, and that of maize silage should be $343 \mathrm{~g} / \mathrm{kg}$. The authors regret the error. 